\title{
Activation and Active Ageing? Mature-Age Jobseekers' Experience of Employment Services
}

\author{
Dina Bowman*, Michael McGann**, Helen Kimberley*** \\ and Simon Biggs**** \\ * Research and Policy Centre, Brotherhood of St Laurence \\ E-mail: dbowman@bsl.org.au \\ ** School of Social and Political Sciences, University of Melbourne \\ E-mail:mmcgann@unimelb.edu.au \\ *** Research and Policy Centre, Brotherhood of St Laurence \\ E-mail: hkimberley@bsl.org.au \\ **** School of Social and Political Sciences, University of Melbourne \\ E-mail: biggss@unimelb.edu.au
}

The number of mature-age Australians registered with employment services is growing, with mature-age jobseekers spending longer unemployed and on income support than younger jobseekers. However, the role of employment services in extending working lives has so far received little attention in policy discourses on ageing and employment. This article examines the effectiveness of Australia's employment services system in supporting mature-age jobseekers, drawing upon interviews conducted as part of wider research on unemployment and underemployment in mature-age. We find that the overriding experience among mature-age jobseekers' is of a system that exudes 'carelessness.' We situate mature-age jobseekers' experiences of systemic carelessness within the context of wider welfare reforms that have contributed to the de-professionalisation and routinisation of employment services' delivery.

Key words: older workers, employment services, unemployment, income support.

\section{Introduction}

In Australia, an increasing number of older people are unemployed and in receipt of income support. The number of mature-age (forty-five plus years) people on unemployment benefits has grown from 154,208 in 2008 to 247,802 mature-age jobseekers in June 2015 (Department of Employment, 2015b). Indeed, mature-age jobseekers account for around 40 per cent of all long-term recipients of unemployment benefits in Australia, spending longer unemployed and on income support than younger jobseekers (Department of Social Services, 2014).

The Organisation for Economic Cooperation and Development (OECD) has called for more extensive job-search requirements for older jobseekers 'as part of a mutual obligations strategy' in response to the increasing rate of mature-age unemployment in OECD countries, citing Australia's Active Participation Model as an innovative approach (2006: 124, 28). This reflects a broader turn 'towards activation' (Finn, 2010; Larsen and 
Wright, 2014: 455) over recent decades, as rights to welfare have increasingly become conditional 'on the basis of individual responsibility to sell one's labour through the market' (Shutes and Taylor, 2014: 204). Australia has often been at the forefront of this turn towards active rather than so-called passive welfare measures, introducing compulsory registration with employment services and mandatory reporting of job-seeking efforts for social security claimants in the late 1980s (Deeming, 2016). Compulsory 'Workfor-the-Dole' followed in the late 1990s, while, today, recipients of unemployment benefits must maintain a specified level of job-seeking effort and periodically perform other 'mutual obligation' activities in order to continue receiving income support. Similar, and even harsher, activation measures have been introduced in other countries, including Britain, where 'jobseekers benefit' claimants must adhere to a 'claimants commitment' or risk having their payments stopped for up to three years (Government UK, 2015).

Until recently, older jobseekers have often been exempted from activation measures such as 'mutual obligation' and 'claimants commitment' requirements; measures that reflect a 'pathological' theory of unemployment based on assumptions of moral or other inadequacies of the unemployed (Marston and McDonald, 2008: 256). As Mestan argues, activation policies are 'only possible if some recipients of government payments are judged as failing to be employed, while the characterisation of welfare dependency assumes that one should be moved into employment' (2014: 10). Unemployment, in this thinking, is linked to negative attitudes to work and low motivation among welfare claimants, with activation policies functioning as technologies of control where 'welfare recipients are shaped as individuals' (Peillon, 1998: 218) into 'self-reliant' citizens responsible for maintaining their wellbeing via market incomes (Marston, 2006: 86). The institutional logic of activation thus amounts to misrecognition of the unemployed in that it constitutes welfare recipients as a deviant social group who must be moved from welfare-to-work in order to become full members of society 'capable of participating on a par with the rest' (Fraser, 2000: 115). A related neo-liberal political rationality can be seen in the turn towards 'active ageing' in policy discourses on population ageing, which similarly maligns those not in work (Moulaert and Biggs, 2013).

'Active ageing' was - and continues to be - narrowly defined in terms of people's capacity 'to lead productive lives in society and the economy' (OECD, 1998: 14, 84). The concept emerged as the principal policy discourse on population ageing and longevity in the late-1990s, when major institutional players such as the European Union and OECD began emphasising older adults' capacity for 'active ageing' in response to growing concerns about the impact of population ageing on social security systems. Higher pension eligibility ages and tighter forms of welfare conditionality began to be introduced to encourage older citizens 'to opt for active ageing opportunities and thus lessen their dependency' (Commission of the European Communities, 1999: 22). In this way, active ageing policies aim to transform older citizens from passive recipients of welfare 'into active lifestyle managers and workers' (Mann, 2007: 285) who 'continue to pursue economic security through employment' (Carmel et al., 2007: 394).

The role of employment services in extending the working lives of mature-age unemployed people has received surprisingly little attention in policy discourses on active ageing, which have largely focused on the role of governments as policymakers rather than facilitators of employment (Pendleton, 2006; Riach and Loretto, 2009). Indeed, governments are increasingly no longer involved in the direct delivery 
of employment services, which have been largely contracted-out to private companies and not-for-profit agencies in countries such as Australia, the Netherlands, Denmark and Britain among others (Bredgaard and Larsen, 2007). Australia, for example, outsourced case management of the long-term unemployed in the mid-1990s, before the Howard Government introduced a comprehensive tendering model, known as Job Network, in the late 1990s. Job Network (1998-2009) has since been replaced by two further iterations of the employment services system - Job Services Australia (2009-15) and job active (from July 2015) - but the quasi-market design of the employment services system has remained, reflecting 'an apparent consensus that welfare-to-work is best delivered by private agencies operating under short-term government contracts' (Considine et al., 2014: 470).

Drawing on interviews with older Australian jobseekers, this article considers how the implementation of active labour market and service delivery reforms has contributed to an employment services system that exhibits 'carelessness' (Lynch, 2010) towards older jobseekers. Writing in the context of higher education, Lynch's concept of 'carelessness' refers to how New Public Management (NPM) of the public sector engenders organisational environments characterised by 'constant surveillance', 'a culture of compliance' and 'a declining sense of responsibility for others' (2010: 55, 57). A related form of 'carelessness', we argue, arises from the 'underlying compulsion' (Marston and McDonald, 2008) of the mature-age jobseeker/employment service provider relationship and manifests in the compliance driven surveillance of jobseekers (Considine et al., 2011). We begin by briefly considering the literature on the impact of NPM on the development of employment services, before introducing the study findings.

\section{NPM and the contracting-out of employment services}

NPM aims to improve the efficiency and cost-effectiveness of government by introducing competition through the incorporation of private agencies into the delivery of public services along with management via performance agreements and contracts (Considine et al., 2014). As Le Grand observes: 'the intention is for the state to stop being both the funder and the provider of services. Instead it is to become primarily a funder, purchasing services from a variety of private, voluntary and public providers, all operating in competition with one' (1991: 1257). Importantly, as Le Grand and Bartlett (1993) showed in relation to quasi-markets for health and welfare services in Britain in the early 1990s, NPM seldom includes direct consumer purchasing and instead involves the disbursement of government funding by (public) purchasing authorities. In this way, the rhetoric of choice is limited to the purchaser not the consumer (Le Grand, 1991).

Marketisation, proponents of NPM argue, can deliver employment services that are more efficient and effective than large public bureaucracies. While there can be no doubt that contracting-out has resulted 'in a fundamentally different employment services system' (Bredgaard and Larsen, 2007: 345), the responsiveness of a quasi-market approach to the needs of long-term and more disadvantaged jobseekers is much disputed. A particular source of controversy is the role played by the use of outcome-based payment models in the provision of support to those who experience the most disadvantage in the labour market (Finn, 2010; Shutes and Taylor, 2014; van Berkel and Borghi, 2008).

Outcome-based payment models, where the allocation of funding is weighted towards payment upon results rather than inputs, are increasingly popular approaches 
to the public financing of service delivery, introducing what Shutes and Taylor describe as another 'form of work-related conditionality in the financing of contracted employment services' (2014: 207). Governments are attracted by such payment models because they shift the risk of investment away from the purchaser on to service providers. However, when combined with hard price competition to win contracts, this stifles innovation and puts pressure on providers to minimise the cost of services and 'to replicate the tried and tested methods' (Larsen and Wright, 2014: 463) over 'more speculative long-term investments' (Fowkes, 2011: 8). Payment-by-results encourages the development of a short-term orientation among providers, with an emphasis on motivating and preparing jobseekers through short-term prevocational and job search training programs rather than through substantive investments in educational activities where outcomes are less certain (Bredgaard and Larsen, 2008: 347; Marston and McDonald, 2008: 265).

Kerr et al. (2002: 85-6) suggest that mature-age jobseekers are likely to be particularly disadvantaged under this model as many have out-dated or superseded skills and require quite specific (and intensive) forms of retraining. Contractual pressures to quickly deliver employment outcomes may also orient providers to steering jobseekers towards relatively low-skilled, low-paid jobs that require little experience or formal training. Riach and Loretto suggest that such low-cost strategies effectively deny mature-age jobseekers' past, as 'individuals who had once been located within skilled or professional occupations' and are likely to be resisted by mature-age jobseekers who refuse to be shoehorned into forms of employment 'very different to their expectations and self-perception of who they [are] as "workers"' (2009: 112, 13).

\section{Distortions in the system}

Related to the short-term orientation of providers is the problem of 'creaming' and 'parking'. 'Creaming' occurs when providers concentrate their efforts on those clients considered 'most likely to trigger an outcome payment' (Rees et al., 2015: 113) while leaving unassisted those deemed hardest to place - 'parking'. Several studies have identified mature-age jobseekers as being particularly vulnerable to parking on the basis that they may be seen as less employable than younger jobseekers due to age discrimination and other factors (Kerr et al., 2002; Pendleton, 2006). Creaming and parking, Bredgaard and Larsen argue, is 'almost unavoidable within a framework of market-economic logic' (2008: 350), despite attempts to reduce it through differential payment structures that pay providers a higher fee for placing jobseekers assessed as having more 'barriers' to employment (Finn, 2010). In Australia, these barriers are identified through the use of a Job Seeker Classification Instrument (JSCI) which classifies jobseekers according to their level of assessed disadvantage in the labour market and identifies those who 'have complex or multiple barriers to employment that need further assessment' (Department of Employment, 2015a). As Rees and colleagues point out, the effectiveness of differential payment structures depends on the extent to which the payments realistically reflect the relative difficulty of assisting claimants into employment, something that has proved difficult to achieve in practice (Rees et al., 2015). Concerns about economically rational incentives for providers to cream and park have generated an almost institutionalised mistrust between authorities and providers that has provoked authorities in many countries to 're-bureaucratise' employment services (Bredgaard 
and Larsen, 2008; Considine et al., 2014: 478). As Bredgaard and Larsen summarise developments in Australia, the Netherlands, and Denmark:

There seems to be a pattern whereby markets are set free in the first tendering round ... After that, the free market competition is gradually reined in by a number of public steering initiatives ... The adding of ever more detailed regulation from the authorities means that the providers' freedom to choose methods as well as flexibility and dynamism are gradually restricted. (2007: 292)

In established quasi-markets, like Australia, providers are under increasing surveillance as administrative systems have 'gradually built up to survey, monitor, and control behaviour in the market' (Bredgaard and Larsen, 2007: 293). In Australia, this has occurred through key performance indicators embedded in contracts and 'the application of an IT-based information system that allows departmental officials to review the activities of frontline operatives' (Marston and McDonald, 2008: 258). As Considine et al. (2011: 827) highlight in their research on contracting-out in Australia, this increased oversight has 'engendered fear of non-compliance in agencies and individuals' with far greater effort going into managing risk, 'often through new forms of service standardisation', and less time going into assisting individual jobseekers. As Sawyer and Green observe in the context of community care in Australia, one of the consequences of adopting routinised procedures in the management of risk is that it 'erodes professional confidence and deskills workers for complex decision making' (2013: 301). Considine et al.'s research demonstrates how this has occurred in Australia as the quasi-market for employment services has become more established. Over the period 1998 to 2008, the frontline employment services staff they surveyed reported an increasing reliance on IT-driven systems to structure their interactions with jobseekers, with staff expressing grave concern about 'doing something wrong and being pulled up from that point of view' (Considine et al., 2011: 819). The qualification levels of frontline workers have declined as IT-driven tools have replaced 'part of the skill set that a case manager might otherwise need' (Considine et al., 2011: 821). This deskilling of frontline workers has been accompanied by a shift in the age profile of those delivering employment services - over 42 per cent of frontline workers in employment services were under thirty-four years of age in 2008 (Considine and Lewis, 2010: 362). This was highlighted by mature-age jobseekers in early research by Encel and Studencki who reported being 'confronted by young, inexperienced staff ... unable to empathise with the problems encountered by older people' (2004: 36).

Below, we highlight how the increased routinisation of service delivery that has accompanied the development of a quasi-market of employment services in Australia has been perceived by mature-age jobseekers. We argue that their experience is one of systemic 'carelessness' which is characterised by service performance rather than meeting needs, underpinned by an emphasis on contractual compliance and cost-cutting and manifest in the employment of young poorly qualified staff.

\section{Methodology}

The data reported are drawn from 120 narrative interviews with mature-age Australians conducted from 2013 to 2014 as part of a mixed methods study on workforce 
Table 1 Characteristics of participants

\begin{tabular}{|c|c|c|c|c|}
\hline & $\begin{array}{l}\text { Newstart } \\
\text { recipients } \\
(n=22)\end{array}$ & $\operatorname{DSP}(n=8)$ & $\begin{array}{l}\text { Voluntary } \\
\text { jobseekers } \\
(n=3)\end{array}$ & Total $(n=33)$ \\
\hline Male & 8 & 2 & 3 & 13 \\
\hline Female & 14 & 6 & & 20 \\
\hline Total & 22 & 8 & 3 & 33 \\
\hline Some secondary school & 1 & & & 1 \\
\hline Vocational certificate & 4 & 3 & 1 & 8 \\
\hline $\begin{array}{l}\text { Diploma or advanced } \\
\text { diploma }\end{array}$ & 6 & 1 & 1 & 8 \\
\hline Undergraduate degree & 7 & 3 & 1 & 10 \\
\hline Post-graduate qualification & 4 & 1 & & 5 \\
\hline Total & 22 & 8 & & 33 \\
\hline $\begin{array}{l}\text { Clerical and administrative } \\
\text { workers }\end{array}$ & 7 & 3 & 3 & 10 \\
\hline $\begin{array}{l}\text { Community and personal } \\
\text { service workers }\end{array}$ & 2 & 2 & & 4 \\
\hline $\begin{array}{l}\text { Machinery operators and } \\
\text { labourers }\end{array}$ & 2 & & & 2 \\
\hline $\begin{array}{l}\text { Technicians and Trades } \\
\text { Workers }\end{array}$ & 3 & 1 & 2 & 6 \\
\hline Professionals and managers & 8 & 2 & 1 & 11 \\
\hline Total & 22 & 8 & 3 & 33 \\
\hline
\end{tabular}

vulnerabilities in midlife and beyond (see McGann et al., 2015). This article reports on interviews with thirty-three of these mature-age Australians. The thirteen men and twenty women were from three areas of Eastern Australia (Western Sydney, the Gold Coast and South East Melbourne) with high levels of mature-age unemployment and were clients, or had recently been clients, of employment services at the time of the study. Participants came from a wide range of occupational backgrounds (see Table 1) and included twenty-two participants who were receiving Newstart Allowance (the allowance paid to unemployed people in Australia), three 'voluntary' clients not receiving activitytested social security payments and eight participants receiving the Disability Support Pension. Although this last group are generally assisted by Disability Employment Services (DES), we have included their perspectives on the basis that DES share many features of mainstream employment services in Australia and are frequently delivered by the same contracted providers (Fowkes, 2011).

Two rounds of semi-structured phone interviews were conducted with participants, with interviews generally lasting between fifty and seventy minutes. During the first interviews in 2013, all participants were asked about the intersection between their age and their experiences of looking for work. The interviews also sought to build a narrative history of participants' experiences of growing up, early employment experiences and most recent experiences of under-employment or looking for work. Interview data were coded thematically and analysed using NVivo software based on a coding scheme developed collaboratively by the authors. In late 2014, twenty-two of the participants 
were re-interviewed to further explore key themes emerging from the data. These included their experiences of the employment services system and perceptions of ageism. The data reported here focus on how participants described the nature and level of their engagement with the employment services system and the activation workers within it.

\section{The 'carelessness' of activation}

The underlying compulsion of activation was reflected in how participants characterised their engagement with employment services, with phrases such as being 'obliged', 'forced' or 'made' to attend frequently colouring their descriptions. For example, a Newstart recipient in her fifties emphasised how she had been 'put into' an employment service that she was now 'obliged to go and see' (Sharon, fifty). Having previously worked in senior administrative roles with pharmaceutical companies, she regarded her appointments as 'a complete waste of everyone's time and money' on the basis that services were disinterested in finding jobs for relatively skilled and experienced jobseekers whereas they 'have [tons] of dishwashers and supermarket packers'. This was a perspective shared by around half of the thirty-three interviewees. As a former software developer commented:

They are really only there to help you if you are looking for trade-like work ... or you have absolutely no idea of how to put a résumé together... Other than that, 'oh I am looking for a job in IT.' 'Oh that's way [above] what I can do.' (Mark, fifty-seven)

Activation policies in Australia are characterised by lack of time given to understanding and assessing jobseekers' needs and capabilities (Fowkes, 2011: 9). In this way, claimants are cast as 'eternal recipients with no past and no future' whose prior work history and contributions are rendered 'invisible or inconsequential' (Kossen and Hammer, 2010: 50). In this study, over a third of participants receiving Newstart Allowance had previously worked in managerial or professional occupations, while many others were experienced clerical or administrative workers. Yet, they reported being processed by staff who were 'just filling their time basically' (Laura, fifty-four):

They will see you for less than two minutes, they just want you to sign that you have been there ... The things that they would tell you, you can find yourself from Seek [an employment site]. (Laura, fifty-four)

Participants reported feeling excluded by the assumption that claimants were necessarily low-skilled jobseekers, seeking manual or entry-level work. This program logic that was reflected in the generic job-search skills training and other forms of support that was offered. There was a frustration among participants about the willingness of providers to just 'plug [them] into something no matter how inappropriate' (Miriam, fiftyfive). For example, several had been directed to apply for jobs as traffic controllers on the basis it was 'an age-appropriate job' (Neil, fifty-five). There was an impression that the primary orientation of providers was to push jobseekers into any job as quickly as possible without taking the time to properly assess their skills-sets, interests or experience. A social worker, Kate (fifty-four), explained in relation to for-profit providers, 'They really want to push you into a job and they just treat you with disrespect basically.' Others suggested that as mature-age jobseekers, they were set aside or parked: 
They probably cater more to the younger crowd ... Those jobs are pretty plentiful - like retail and hospitality or those kinds of things. And that's the easiest path to take, whereas ... we kind of get put on a side rail. (Jim, fifty-five)

Participants' accounts of attending appointments suggested that activation was seen as something that was to be performed rather than achieved in the jobseekerprovider relationship, with employment services staff perceived as performing 'more of a monitoring role' (Jim, fifty-five) than actually helping people to find work. The interviewees expressed a level of emotional divestment about the activation process, as reflected in the comments of a former advertising professional who was required to respond to twelve job advertisements per week in addition to cold-calling five employers:

It's a useless appointment ... to get money every fortnight, I have to tell a whole bunch of lies because I couldn't possibly do what they ask me ... You end up making up a report to tick the boxes ... As long as you actually march to the beat of the drum, tick all the boxes that are required ... they don't really care. They kick you off and give you another appointment three weeks later and the cycle continues. (Ed, emphasis added)

The mature-age jobseekers interviewed saw employment service providers as engaged in a process of activation, driven by the imperative 'to get [jobseekers] through the processing' (Sarah, fifty-eight) and demonstrate that they've 'ticked the boxes ... met the KPIs [key performance indicators]' (Neil, fifty-five). As a jobseeker in her mid-fifties observed:

Sometimes I think the things they do have nothing to do with helping me, but just to make them look like they're doing something, and they're not really doing something. (Miriam, emphasis added)

This calls to mind Lynch's observations about the 'intensification of carelessness' and 'culture of compliance' fostered by new managerialist approaches (Lynch, 2010: 55, 57).

\section{Age mismatch}

The young age and relative inexperience of frontline services staff was frequently commented upon by participants, who suggested the employment consultants dealing with them 'have [either] not been very professional or they're very, very young' (Miriam, fifty-five). Interestingly, they perceived that this contributed to a more routinised approach rather than the other way round. The difference in age of the jobseeker and the employment services staff compounded the sense of systemic carelessness:

Whether you like it or not, there's always a bias about it ... They look at you like they're going to be kind of hesitant to tell you or something. (Veronica, sixty)

Those with experience of dealing with older frontline workers suggested that staff closer to their own age were better positioned to understand their situation than 'a young person who's been there for about six months whose job is to tick you off the list and push you into a course' (Ed, fifty-four). This led to calls by some participants to 'put older staff in there, people with real life experience' (Neil, fifty-five). Several interviewees 
felt that it was 'hard to get through what it's like' to consultants twenty or thirty years younger 'because they're so young for the most part, they think they've got it all, think they know it all' (Kevin, fifty-one). One participant in his sixties felt that young female employment consultants, in particular, might feel intimated by having to deal with older male jobseekers: 'I get that feeling sometimes, because you are like their father' (Les, sixty-one). Ed (fifty-four), a long-term jobseeker, described an occasion when an older employment consultant filled in for his regular caseworker:

Probably they can relate to my circumstances a bit more ... We talked about more of the issues that I experienced rather than how many boxes I had to tick. And that's the thing that a twenty-four-year-old in their first job out of the uni, I mean, what's she going to tell me?

Of course, such positive appraisals of older compared with younger employment services staff may reflect participants' own prejudices against younger people. Indeed, some participants acknowledged that older consultants have on occasion been 'if anything ... worse' (Kevin, fifty-one). Nevertheless, there is an element of symbolic violence about a system that relies on largely inexperienced consultants to supervise the activation of jobseekers with extensive work histories and contributions to the labour market. In the absence of significant 'life and work experience skills', these young employment consultants were perceived as 'just regurgitat[ing] what they got taught at the university and/or the company's policies and procedures with little understanding about [the] human condition' (Neil, fifty-five).

\section{Discussion}

As Considine and Lewis observe, the implementation reforms that have accompanied the activation turn in Australian social policy have resulted in 'a sea-change in the way public services for jobseekers are imagined and enacted' (2010: 358). Not only has the delivery of these services been largely privatised, managerialism and the increased adoption of risk management and performative technologies have substantively changed the nature of the work undertaken by employment services workers. Human-service practice has been partially transformed from 'street-level' to 'screen-level' bureaucracy, with much of the work becoming heavily proceduralised and decisions 'made on the basis of entering responses to standardised questions into a computer program' (Marston, 2006: 92).

Writing in the context of the use of performative technologies within higher education, Lynch cautions that '[i]ncessant auditing and measuring is a recipe for self-display and the fabrication of image over substance' (2010: 55). It directs attention to the measurable, no matter how inappropriate, as Lynch point out, '[e]verything one does must be counted, and only the measurable matters' (2010: 55).

For the mature-age jobseekers in this study, the employment services system is similarly experienced as driven by the measurement and display of activation rather than the attainment of employment. This is reflected by the recurring metaphor of 'ticking the boxes' in participants' accounts of interacting with employment services staff. A sense of 'carelessness' pervades the jobseeker-provider relationship: both for the mature-age jobseekers, who view participation in employment service activities as a waste of their time, but which they perform to continue receiving income support, and for employment services' staff, who are perceived as having little motivation or 
expertise beyond getting jobseekers through the processing. The 'carelessness' described is systemic rather than personal, a sort of 'institutional indifference' (Sennett, 2006: 124). It stems from a heavy emphasis on managerial notions of accountability and the use of performative technologies, which 'can diminish the capacity for choice and agency and de-individualise service delivery for both employees and the long-term unemployed' (Marston, 2006: 98). This manifests in a lack of personal attention from seemingly disinterested providers, with mature-age jobseekers systemically misrecognised, as Riach and Loretto found in their research on older jobseekers in the UK, 'being offered low skilled, badly paid jobs ... based upon their status as disabled or older, rather than their experience or skills set' (2009: 112).

For mature-age jobseekers, the proceduralism and 'carelessness' of the employment services system is compounded by the relative age of the employment consultants managing their activation. As Considine and Lewis' (2010) research on frontline workers within Australian employment services has shown, the de-skilling of employment services' work has substantially reduced the average age of those delivering employment services, over 40 per cent of whom are under 34. While negative age-based stereotyping and discrimination by employers is widely recognised as a major barrier facing matureage jobseekers, the role of the structural features of the labour market in mediating experiences of discrimination has been less examined. The comparatively young age of employment consultants and other 'gatekeepers' in the labour market is one such feature, with perspectives in social psychology suggesting that people are 'more inclined to attribute positive characteristics to members of their own group (in-group bias) and more negative characteristics to members of other groups (out-group bias)' (Henkens, 2005: 355-6). For example, in research commissioned by the Australian Human Rights Commission (2013: 39), younger managers and recruiters were more likely to believe negative stereotypes about older workers, with around half of those under thirty-five holding predominantly negative attitudes. Similarly, our study highlighted the potential for unconscious bias by young employment services' staff, who mature-aged jobseekers perceived as either being unwilling or incapable of appreciating the circumstances and needs of older unemployed people (cf. Encel and Studencki, 2004).

\section{Conclusion}

Drawing on Bourdieu's concept of 'misrecognition', Peillon (1998: 221) argues that '[w]elfare agencies and welfare clients belong to a structure of domination, but one which is largely misrecognised ... as caring'. The organisation of the relationship between agencies and recipients in terms of control is particularly evident in the jobseekerprovider relationship, where the parties have come together because they are required to do so .... [not] because the unemployed person believes that the employment service will offer them the assistance they need' (Marston and McDonald, 2008: 2634). Systemic 'carelessness' pervades this relationship and is produced by a system that relies increasingly on technologies of control to monitor and survey the activation of welfare recipients. This reflects how the development of activation policies has shaped the nature of service delivery. Contractual compliance and the need to be financially efficient has de-professionalised employment services and undermined their ability to effectively support mature-age unemployed jobseekers. In turn, the age mismatch between mature-age jobseekers and frontline staff compounds preconceptions and job-matching 
and motivational strategies that fail to recognise mature-age jobseekers' capabilities and work histories.

\section{Acknowledgements}

The research for this article was funded by ARC Linkage Grant LP120100624. The authors would like to thank the Australian Research Council and project partners, Jobs Australia and the Brotherhood of St Laurence, for their support. We are also grateful to the reviewers, whose insightful comments and suggestions helped to strengthen this article.

\section{References}

Australian Human Rights Commission (2013) Fact or Fiction? Stereotypes of Older Australians, Australian Human Rights Commission.

Bredgaard, T. and Larsen, F. (2007) 'Implementing public employmnet policy: what happens when nonpublic agencies take over?', International Journal of Sociology and Social Policy, 27, 7/8, 287-300.

Bredgaard, T. and Larsen, F. (2008) 'Quasi-markets in employment policy: do they deliver on promises?', Social Policy and Society, 7, 3, 341-52.

Carmel, E., Hamblin, K. and Papadopoulos, T. (2007) 'Governing the activation of older workers in the European Union: the construction of the "activated retiree"', International Journal of Sociology and Social Policy, 27, 9/10, 387-400.

Commission of the European Communities (1999) Towards a Europe for All Ages: Promoting Prosperity and Intergenerational Solidarity, Commission of the European Communities.

Considine, M. and Lewis, J. M. (2010) 'Front-line work in employment services after ten years of new public management reform: governance and activation in Australia, the Netherlands and the UK', European Journal of Social Security, 12, 4, 357-70.

Considine, M., Lewis, J. M. and O'Sullivan, S. (2011) 'Quasi-markets and service delivery flexibility following a decade of employment assistance reform in Australia', Journal of Social Policy, 40, 4, $811-33$

Considine, M., O'Sullivan, S. and Nguyen, P. (2014) 'New public management and welfare-to-work in Australia: comparing the reform agendas of the ALP and Coalition', Australian Journal of Political Science, 49, 3, 469-85.

Deeming, C. (2016) 'Rethinking social policy and society', Social Policy and Society, 15, 2, 159-75.

Department of Employment (2015a) Job Seeker Classification Instrument, https://www.employment. gov.au/job-seeker-classification-instrument [accessed on 02.11.15].

Department of Employment (2015b) Job Services Australia Data June 2015 - Newstart Customer Population by Age Group, Commonwealth of Australia, http://lmip.gov.au/default.aspx?LMIP/ EmploymentData_obServicesAustraliaNewstartRecipientsbyAge [accessed on 20.07.15].

Department of Social Services (2014) Income Support Customers: A Statistical Overview 2013, Canberra: Commenwealth of Australia.

Encel, S. and Studencki, H. (2004) 'Older workers: can they succeed in the job market?', Australasian Journal on Ageing, 23, 1, 33-37.

Finn, D. (2010) 'Outsourcing employment programmes: contract design and differential prices', European Journal of Social Security, 12, 4, 289-302.

Fowkes, L. (2011) Rethinking Australia's Employment Services, Whitlam Institute, the University of Western Sydney.

Fraser, N. (2000) 'Rethinking recognition', New Left Review, 3, May/June, 107-20.

Government, UK (2015) Jobseekers' Allowance (JSA), https://www.gov.uk/jobseekers-allowance/furtherinformation [accessed 02.11.15]. 
Henkens, K. (2005) 'Stereotyping older workers and retirement: the managers' point of view', Canadian Journal on Aging, 24, 4, 353-66.

Kerr, L., Carson, E. and Goddard, J. (2002) 'Contractualism, employment services and mature-age jobseekers', The Drawing Board: An Australian Review of Public Affairs, 3, 2, 83-104.

Kossen, C. and Hammer, S. (2010) 'Mature-aged job seekers' experiences of Centrelink and the job network services in an Australian regional centre', Australian Journal of Career Development, 19, 1, 45-53.

Larsen, F. and Wright, S. (2014) 'Interpreting the marketization of employment services in Great Britain and Denmark', Journal of European Social Policy, 24, 5, 455-69.

Le Grand, J. (1991) 'Quasi-markets and social policy', The Economic Journal, 101, 1256-67.

Le Grand, J. and Bartlett, W. (eds.) (1993) Quasi-Markets and Social Policy, London: Macmillan.

Lynch, K. (2010) 'Carelessness: a hidden dox of higher education', Arts and Humanities in Higher Education, 9, 54-67.

Mann, K. (2007) 'Activation, retirement planning and restraining the "Third Age"', Social Policy and Society, 6, 3, 279-92.

Marston, G. (2006) 'Employment services in an age of e-government', Information, Communication and Society, 9, 1, 83-101.

Marston, G. and McDonald, C. (2008) 'Feeling motivated yet? Long-term unemployed people's perspectives on the implementation of workfare in Australia', Australian Journal of Social Issues, 43, 2, 255-69.

McGann, M., Bowman, D., Kimberley, H. and Biggs, S. (2015) Too Old to Work, Too Young to Retire, Melbourne: Brotherhood of St Laurence, http://library.bsl.org.au/jspui/bitstream/1/7905/ 4/Workforce_vulnerabilities_in_midlife_and_beyond_research_summary_2015.pdf.

Mestan, K. (2014) 'Paternalism in Australian welfare policy', Australian Journal of Social Issues, 49, 1, $3-22$.

Moulaert, T. and Biggs, S. (2013) 'International and European policy on work and retirement: reinventing critical perspectives on active ageing and mature subjectivity', Human Relations, 66, 1, 23-43.

OECD (1998) Maintaining Prosperity in an Ageing Society, Paris: Organisation for Economic Cooperation and Development.

OECD (2006) Ageing and Employment Policies: Live Longer, Work Longer, Paris: Organisation for Economic Co-operation and Development.

Peillon, M. (1998) 'Bourdieu's field and the sociology of welfare', Journal of Social Policy, 27, 2, 213-29.

Pendleton, N. (2006) 'Getting people back into work: the experience of Jobcentre Plus', Social Policy and Society, 5, 4, 533-39.

Rees, J., Whitworth, A. and Carter, E. (2015) 'Support for all in the UK Work Programme? Differential payments, same old problem', in M. Considine and S. O'Sullivan (eds.), Contracting-Out Welfare Services: Comparing National Policy Designs for Unemployment Assistance, Oxford: Wiley Blackwell, 109-28.

Riach, K. and Loretto, W. (2009) 'Identity work and the "unemployed" older worker: age, disability and the lived experience of the older unemployed', Work, Employment and Society, 23, 1, 102-19.

Sawyer, A.-M. and Green, D. (2013) 'Social inclusion and individualised service provision in high risk community care: balancing regulation, judgment and discretion', Social Policy and Society, 12, 2, 299-308.

Sennet, R. (2006) The Culture of the New Capitalism, New Haven, CT: Yale University Press.

Shutes, I. and Taylor, R. (2014) 'Conditionality and the financing of employment services: implications for the social divisions of work and welfare', Social Policy and Administration, 48, 2, 204-20.

van Berkel, R. and Borghi, V. (2008) 'Review article: the governance of activation', Social Policy and Society, 7, 3, 393-402. 